\title{
UNIVERSAL PRECAUTION KNOWLEDGE LEVELS IN POSTGRADUATE STUDENTS FACULTY OF DENTISTRY
} (TINGKAT PENGETAHUAN MENGENAI UNIVERSAL PRECAUTION PADA MAHASISWA PROGRAM PROFESI DOKTER GIGI FAKULTAS KEDOKTERAN GIGI)

Jhds.fkg.unjani.ac.id DOI:10.54052/jhds.v1n1.p7179

Article History

Received:09/02/2021

Accepted: 09/03/2021
Sri Sarwendah $^{1 *}$, Syarif Suwondo ${ }^{1}$, Irena Nisa Harliani ${ }^{1}$

${ }^{1}$ Departement of Dental Public Health, Faculty of Dentistry, Universitas Jenderal Achmad Yani, Cimahi, Indonesia

*Corresponding author

ciek2012@ymail.com

\begin{abstract}
Universal precautions are one way to prevent the transmission of disease, which is transmitted by blood and all body fluids, including saliva, either from the patient to health worker and from patient to another patient. Patients should be treated as infected with the disease and potentially infectious every time. This action should be done by all health care staff in the risk of cross-infection between patients, and health workers can be minimized. Basic universal precautions include immunization, hand washing, personal protective equipment, medical equipment management, and hospital waste management. This study aims to describe the level of knowledge about universal precautions in postgraduate students Faculty of Dentistry Universitas Jenderal Achmad Yani Cimahi (Unjani). This study used a descriptive design by cross-sectional. Collection data for research using a questionnaire containing 20 questions tested for validity and reliability, then a questionnaire filled out by respondents as many as 40 people. Presentation of research data is processed and presented to illustrate the level of knowledge in postgraduate students of frequency distribution table. The results showed that most of postgraduate students has a high knowledge (60\%), postgraduate students with a moderate level of knowledge (27.5\%), and postgraduate students with the knowledge that a low level (12.5\%). Conclusions of the research showed that the majority postgraduate students about universal precaution is at a high level.
\end{abstract}


Keywords: universal precaution, knowledge level

\begin{abstract}
ABSTRAK
Kewaspadaan universal merupakan salah satu cara untuk mencegah penularan penyakit yang ditularkan melalui darah dan seluruh cairan tubuh termasuk air liur, baik dari pasien ke petugas kesehatan maupun dari pasien ke pasien lainnya, sehingga semua pasien harus diperlakukan sebagaimana adanya penyakit tersebut. dan berpotensi menularkan setiap saat. Tindakan ini harus dilakukan oleh semua petugas kesehatan agar risiko infeksi silang antara pasien dan petugas kesehatan dapat diminimalkan. Kewaspadaan dasar universal meliputi imunisasi, cuci tangan, penggunaan alat pelindung diri, pengelolaan peralatan medis dan pengelolaan limbah rumah sakit. Tujuan dari penelitian ini adalah untuk mendeskripsikan tingkat pengetahuan tentang kewaspadaan universal pada mahasiswa kepaniteraan Fakultas Kedokteran Gigi Unjani. Penelitian ini menggunakan desain deskriptif dengan pendekatan cross-sectional. Pengumpulan data untuk penelitian yaitu dengan menggunakan kuesioner yang berisi 20 pertanyaan yang telah diuji validitas dan reliabilitasnya kemudian kuesioner diisi oleh responden sebanyak 40 orang. Penyajian data penelitian diolah dan disajikan untuk menggambarkan tingkat pengetahuan kepegawaian tabel distribusi frekuensi. Hasil penelitian menunjukkan bahwa sebagian besar kepaniteraan memiliki pengetahuan yang tinggi (60\%), kepaniteraan dengan tingkat pengetahuan sedang (27,5\%), dan kepaniteraan dengan tingkat pengetahuan yang rendah (12,5\%). Kesimpulan dari penelitian ini adalah mayoritas mahasiswa kepaniteraan Kedokteran Gigi Unjani tentang kewaspadaan universal berada pada taraf tinggi (60\%).
\end{abstract}

Kata kunci: kewaspadaan universal; tingkat pengetahuan

\section{INTRODUCTION}

Apart from being a place to seek healing for sufferers of various diseases, hospitals can spread multiple disease agents, especially infectious diseases. The disease agent brought the patient from outside the hospital, which ends up on the air, floor, non-medical equipment, water, and even food that has been prepared from the hospital. Cross infection can occur and is defined as transmitting an infectious agent between the patient and staff in a clinical setting. ${ }^{1}$ Infection is one of the health problems in 
the world, including in Indonesia. Infection can come from the community (community-acquired infection) or come from the environment (hospitalacquired infection), commonly known as nosocomial infection. ${ }^{2}$

Dentists in carrying out their profession cannot be separated from the possibility of being infected with various agents from the patient. The spread can be through multiple transmission, direct contact, indirect contact, droplets, and airborne infections. Diseases transmitted during dental care include tuberculosis, hepatitis, HIV/AIDS, herpes, and rubella. ${ }^{1}$

Every year, hundreds of thousands of workers in the health sector are exposed to deadly viruses such as hepatitis and Human Immunodeficiency Virus (HIV) due to needle stick injuries and sharp objects. Health care workers are infected with more than 20 bloodborne pathogens because of infections. There are an estimated1,000 people per year. The most common is hepatitis $\mathrm{B}$, hepatitis $\mathrm{C}$ and HIV. In November 2002, the world Health Report published data showing that $2,5 \%$ of HIV cases among health care workers and $40 \%$ of hepatitis B and C cases among health care workers worldwide were the result of exposure. Evidence in world health reports shows a high risk of spreading infection among medical personnel, so efforts should be made to protect, prevent, and minimize cross-infection by applying universal precautions. The basis for infection control is the existence of infection control which consists of immunization, washing hands, wearing personal protective equipment including gloves, masks, protective clothing, protective goggles to prevent contact with management and health, including blood or fluids, management of medical devices including sterilization and disinfection as well as waste management. ${ }^{3,4}$

Since 2001, the ministry of health has included control of nosocomial infections as one of the benchmarks for hospital accreditation. The benchmarks include the application of universal precaution as an effort to work health and safety. 5 Occupational health and safety is part of public health that relates to all jobs and is associated with potential factors to affect the health of workers. Occupational health and safety is the right of all people who work, including medical personnel. ${ }^{6}$

The author wants to examine how much knowledge the Dentist Education Professional Program students, Faculty of Dentistry Unjani, about universal precautions. Researchers took samples from students at the professional stage because, in dentistry, they often contact blood and saliva to contaminate the hands, so the infection control procedure (universal precaution) must be aimed at all patients and for all dental precautions.

\section{METHOD}

The research design used in this study was descriptive in a cross-sectional manner because this research was conducted in the field and data collection. In the cross-sectional study, the researcher did not follow up on the measurements carried out. ${ }^{7,8}$ The target population in this study were all students of the Dental Education Professional Program at the Faculty of Dentistry, 
Unjani. They were taken based on the following inclusion and exclusion criteria. Inclusion Criteria, namely students registered as active students of the Dental Education Professional Program, Faculty of Dentistry Unjani, and Willing to be respondents. Exclusion Criteria, namely students who do not collect questionnaire sheets and students who are not present at the research time. Samples were taken by total sampling.

Researchers took samples where the samples were the same as the population-based on inclusion and exclusion criteria. Based on the data obtained by researchers from the student affairs section, the number of samples that met the inclusion criteria was 41 people. They completed the photocall sampling requirements, namely the number of less than $100 \mathrm{sch}$, so that the entire population became the study sample. ${ }^{9}$ The research procedure began with making a questionnaire, and then the researcher submitted a license to the secretary of the dentist education professional program in ward 8 of Dustira hospital. Validity and reliability tests will be carried out before the questionnaire is given to respondents. Variable data were taken simultaneously, then the description of the level of knowledge of professional program students about universal precautions was assessed in the low category, moderate, and high.

Research instruments are important in quantitative research because the quality of the data obtained is in many ways determined by the quality of the instruments used. If the instrument used can be accounted for, the data obtained could be accounted for. The data in question can represent or reflect a situation that is measured on the research subject. ${ }^{9}$ Processing and data analysis of the questionnaire sheet was carried out using a frequency distribution table based on: semester, age and gender. This study used univariate data analysis, which aims to describe the characteristics of each research variable. In this study, the researcher explains the benefits, objectives, and possible risks and inconveniences caused. The researcher also guarantees the anonymity and confidentiality of the identity and information provided by the respondent, but it is enough to use the code. Researchers prepare informed consent to be obtained by the respondent, and the respondent has the right to resign as an object of research at any time. Researchers maintain the principle of openness by explaining research procedures. This principle of justice guarantees that all research subjects receive the same treatment regardless of the type of sex, religion, etc. ${ }^{10}$

\section{RESULT}

Description of respondent characteristics respondents who were sampled in this study were 40 Dentist Education Professional students. The characteristics of the respondents observed were several semesters in the Dentist Education Professional Program (P3DG) students, age, and gender.

Table 1. Frequency distribution by semester

\begin{tabular}{ccll}
\hline No & Semester & F & \% \\
\hline 1 & I & 14 & 35 \\
2 & II & 20 & 50 \\
3 & III & 2 & 5 \\
4 & IV & 4 & 10 \\
\hline
\end{tabular}




\section{Total}

$40 \quad 100$

The table above shows that the number of student respondents in the Dental Education Professional Program (P3DG) Faculty of Dentistry Unjani based on semester was half of them come from the second semester $(50.0 \%)$. A small proportion of them came from the first semester (35\%) and a little originating from semester II (5\%) and IV (10\%).

Table 2. Frequency distribution by age

\begin{tabular}{llll}
\hline No & Respondent Age & F & \% \\
\hline 1 & 20 years & 1 & 2.50 \\
2 & 21 years & 2 & 5.00 \\
3 & 22 years & 23 & 57.50 \\
4 & 23 years & 10 & 25.00 \\
5 & 24 years & 3 & 7.50 \\
6 & 25 years & 1 & 2.50 \\
Total & & $\mathbf{4 0}$ & $10 \mathrm{o}$ \\
\hline
\end{tabular}

Table 2 showed that the respondent age was mostly 22 years old $(57.5 \%)$, was 23 years old $(25 \%)$. At least there were at the age of 20,21, 24 and 25 years.

Table 3. Frequency distribution by gender

\begin{tabular}{llll}
\hline No & Gender & F & \% \\
\hline 1 & Male & 7 & 17.5 \\
2 & Female & 33 & 82.5 \\
\multicolumn{2}{l}{ Total } & $\mathbf{4 0}$ & $\mathbf{1 0 0}$ \\
\hline
\end{tabular}

Table 4.3 above shows, it is known that the number of student respondents in the Dental Education Professional Program (P3DG), Faculty of Dentistry, Unjani is almost all women $(82.50 \%)$, and a few of them are male respondents(17.5\%).

Table 4. Distribution of age frequency by gender

\begin{tabular}{llll}
\hline Age & Gender & & \\
& Male & Female & Total \\
\hline
\end{tabular}

\begin{tabular}{|c|c|c|c|c|c|c|c|c|c|c|}
\hline \multicolumn{4}{|c|}{ The Universal Precaution Dimension of Knowledge } & Low & \multicolumn{2}{|c|}{ Moderate } & \multicolumn{2}{|c|}{ High } & \multicolumn{2}{|c|}{ Total } \\
\hline ane uiversal rt & IVIII & 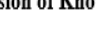 & lieuge & $f \%$ & $6 \quad \mathrm{~F}$ & $\%$ & F & $\%$ & & $\%$ \\
\hline Definition and pur & & & & 00 & 00 & 0.0 & 40 & 100.0 & 40 & 100.0 \\
\hline Basics & & & & 51 & 2.511 & 1127. & 524 & 60.0 & 40 & 100.0 \\
\hline Immunization & & & & 00 & 01 & 2.5 & 39 & 97.5 & 40 & 100.0 \\
\hline Hand wash & & & & 00 & 00 & 0.0 & 40 & 100.0 & 40 & 100.0 \\
\hline \multicolumn{3}{|c|}{ Personal protective equipment } & 5 & $\begin{array}{l}12 . \\
5\end{array}$ & 9 & 22.5 & 26 & 65.0 & 40 & 100.0 \\
\hline \multicolumn{3}{|c|}{ Medical device management } & 2 & 5.0 & 11 & 27.5 & 27 & 67.5 & 40 & 100.0 \\
\hline \multicolumn{3}{|c|}{ Hospital waste management } & 6 & $\begin{array}{l}15 . \\
0\end{array}$ & 5 & 12.5 & 29 & 72.5 & 40 & 100,0 \\
\hline & $\mathrm{F}$ & $\%$ & $\mathrm{~F}$ & & $\%$ & & $\mathrm{~F}$ & & $\%$ & \\
\hline 20 years & 0 & 0.0 & 1 & & 3.0 & & 1 & & 2.5 & \\
\hline 21 years & 0 & 0.0 & 2 & & 6.1 & & 2 & & 5.0 & \\
\hline 22 years & 2 & 28.6 & & 1 & 63. & & & 23 & 57. & \\
\hline 23 years & 5 & 71.4 & 5 & & 15. & & & 10 & 25. & \\
\hline 24 years & 0 & 0.0 & 3 & & 9.1 & & 3 & & 7.5 & \\
\hline 25 years & 0 & 0.0 & 1 & & 3.0 & & 1 & & 2.5 & \\
\hline Total & 7 & 100 & & 3 & 10 & & & 40 & 100 & \\
\hline
\end{tabular}

From the table above, the age distribution of respondents in the 22-year-old respondent group $(57.5 \%)$ found that there were more female respondents than male respondents.

The respondents' level of knowledge about universal precautions in general and knowledge about universal precautions is divided into three categories: high knowledge, moderate knowledge, and insufficient knowledge. The frequency distribution of aspects or dimensions of knowledge regarding universal precautions is presented in table 4.5 . 
Table 5. Frequency distribution of universal precaution aspects of knowledge

In Table 5, the level of universal precautionary knowledge taken from each item of the question in the questionnaire conducted almost all have good/high knowledge about the definition and purpose of universal precaution, immunization and hand washing. The aspect of knowledge about the basics of universal precaution is known that most students have the high ability $(60 \%), 11$ people have moderate knowledge (27.5\%), and five people have insufficient knowledge (12.5\%). The aspect of knowledge regarding the basics of universal precaution, which consists of personal protective equipment, shows that 26 people $(65 \%)$ have high knowledge. The management of medical devices is known as 27 people (67.5\%) have high knowledge, while the management of household waste is 29 people $(72.5 \%)$.

The level of knowledge was calculated using interval class lengths, determining the minimum and maximum class so that the score range for each class is obtained. The results showed the percentage of respondents in three categories of knowledge levels about universal precautions. In general, 24 people (60\%) have high knowledge, 11 people have moderate knowledge of universal precautions $(27.5 \%)$, and five people (12.5\%) have low knowledge about universal precautions.

\section{DISCUSSION}

Students are currently studying in tertiary institutions between the ages of 19 and 28, experiencing a transition from adolescence to adulthood. Students can be defined as individuals studying at the tertiary level, both public and private or other institutions at the university level. Students are considered to have a high level of intellect, intelligence in thinking and planning in action. ${ }^{11}$

According to Webster, a profession is a job that requires a long education and involves intellectual skills. A profession is also a position or job that demands expertise from its members. The above limitation implies that work or employment called a profession can only be done by a person who has expertise. $^{12}$

Dentist education professional program students are students with professional academic education and can be taken after graduating from a Bachelor of Dentistry. This program is clinical learning experiences and community learning conducted at the Dental and Oral Teaching Hospital (RSGMP). ${ }^{13}$

Universal precaution is a method to prevent disease transmission from the patient's blood and all body fluids, including saliva, to the health care worker and patient. All patients must be treated as if they are infected with a disease and are potentially contagious at all times. ${ }^{3,14,15}$

The transmission mode of the disease can be in several ways, namely, direct transmission of the disease, namely direct contact with body fluids such as saliva and blood. Transmission of the disease is indirect; when infectedmicroorganisms contaminate the instrument's surface, the instrument touches a person. Cross-contamination refers to transmitting microorganisms from source to person and 
transmission of disease from one person to another. Transmission through parenteral exposure can also occur when infected instruments puncture health workers. ${ }^{16}$

In the mid-1990s, the Centers for Disease Control and Prevention (CDC) mentioned the concept of universal precaution as a standard precaution. The idea of standard precaution is the same as a universal precaution, namely reducing the risk of transmission of infectious microorganisms in the hospital, whether from recognized sources or not. Standard precautions are applied to blood, all body fluids, secretions and excretions except sweat, regardless of whether they contain blood or not, non-intact skin and mucous membranes. ${ }^{14,15,17}$ The basis for infection control is the presence of infection control consisting of personal protection such as immunization, hand washing, use of protective equipment including gloves, masks, protective goggles and protective clothing, management of medical devices and waste management. ${ }^{18}$

In disease transmission, hands can be a medium for transmitting disease for the transmission of blood and saliva from harmful microorganisms, especially under the nails.

Washing hands is the most important action and is one of the ways to prevent disease transmission. The main purpose is to prevent the transmission of pathogenic germs quickly and effectively. ${ }^{19}$

The management of medical devices aims to prevent the spread of infection through medical devices or to ensure that these devices are always sterile and ready to use. Almost all equipment in the hospital can be occupied and grown by microorganisms. On that basis, all equipment that will come into contact with the patient must be sterile. $^{20}$

According to Juliana, knowledge is related to age; namely, the younger the individual's age, the higher the ability to remember the information received. The older the individual, the more physiological changes in the body reduce the ability to recall information received. Based on age data, all respondents are in young and middle adulthood, so they can remember the information received. ${ }^{12}$

Navissha (2011) states that the knowledge, attitudes, and behaviour of clinical postgraduate students towards universal precautions at RSGMP FKG USU Medan showed that $48.75 \%$ of students had sufficient knowledge. Due to the absence of supervision from the supervisory lecturer. The lack of fixed procedures regarding universal precautions at the USU Dental Hospital is due to the absence of control from the supervisory lecturer. However, the research conducted by Sreedharan et al. (2011) in Saudi Arabia showed that as many as $97 \%$ of students had good knowledge about universal precautions. The results of Sreedharan's research are the same as the study results conducted on students of the Dental Education Professional Program (P3DG) of the Faculty of Dentistry, Unjani that the majority of knowledge is good. The work follows the Ministry of Health's regulation which includes control of nosocomial infections as one of the benchmarks for hospital accreditation which 
consists of the application of universal precautions as an effort to work health and safety. ${ }^{3,21}$

Students who lack knowledge about universal precautions influence their attitudes and actions when treating patients so that the risk of cross-infection between medical personnel and patients increases.

\section{CONCLUSION}

The description of the level of knowledge about universal precaution among students of the Dental Education Professional Program (P3DG), Faculty of Dentistry, Unjani, has a high level of knowledge. Based on the knowledge aspect, the definition and purpose of universal precaution are in the high category, while the level of knowledge about the basics of universal precaution, including personal protective equipment, management of medical devices, and hospital waste management, was in a low category.

\section{CONFLICT OF INTEREST}

We declare that there is no conflict of interest in the scientific articles.

\section{ACKNOWLEDGEMENT}

Our gratitude goes to the professionals who have helped research funder, research materials and facilities: LPPM Unjani.

\section{REFERENCES}

1. Miller, C. H. \& Palenik, C. J., 2005. Infection Control and Management of Hazardous Materials for the Dental Team. In: JHDS
s.1.:Philadelphia: Elsevier Mosby, pp. 36-37,111115,130-140.

2. Spicer, W. J., 2008. Clinical Microbiology and Infectious Diseases. In: St.Louis: St.Louis: Elsevier, pp. 218-219.

3. Pankhurst, C. \& Coulter, W., 2009. Basic Guide to Infection Prevention and Control In Dentistry. In: New Delhi India: Wiley Blackwell, pp. 18-25.

4. Chandra, d., 2011. Proteksi Dari Resiko Infeksi Nosokomial. http://redesain.poltekkesmalang.ac.id/index.php/rumah/detail/artikel/157 $/ 157$.

5. D. K., 2008. Pedoman pencegahan dan pengendalian infeksi di rumah sakit dan fasilitas pelayanan kesehatan lainnya. Jakarta: Depkes.

6. U. A., 2008. Buku pedoman pelaksanaan kesehatan dan keselamatan kerja untuk praktek dan praktikum. Surabaya: Unair.

7. C. B., 2006. Pengantar kesehatan lingkungan. In: Jakarta: EGC, pp. 191-193.

8. D. M., 2013. Statistik untuk kedokteran dan kesehatan. In: Jakarta: Salemba Medika, pp. 1-60.

9. Sudigdo, S. \& S, I., 2002. Dasar - dasar metodologi penelitian klinis. In: Jakarta: Sagung Seto, pp. 79-96. 10. D, J. S., 2012. Analisis validitas dan asumsi klasik. Yogyakarta: Gava Media.

11. Departemen Pendidikan Nasional (Depdiknas). 2008. Kamus Besar Bahasa Indonesia. Jakarta: Depdiknas.

12. Kusnanto. 2003. Pengantar Profesi \& Praktik Keperawatan Profesional. Jakarta: EGC. 
13. Undang - undang Republik Indonesi (UU RI). 2013. UU RI Tahun 2013 Tentang PraktikKedokteran. Jakarta.

14. Samaranayake L . 2006. "Essential Microbiology For Dentistry." 309. St.Louis: Elsevier.

15. Robinson DS, and Doni LB. 2007. Essentials of Dental Assisting. 4th. St.Louis:Elsevier.

16. Irlbacher-Girtel, and Guy SG. 1010. Dental Office Administration.Philadelphia:Lippincott Williams \& Wilkins.

17. Ikatan Dokter Anak Indonesia (IDAI). 2012. Buku Ajar Infeksi \& Pediatri Tropis.Jakarta: IDAI.

18. Marsh PS, and Michael VM. 2009. Oral Microbiology. 4th. St.Louis: Elsevier.
19. Apriany D. 2012. "Perbedaan Perilaku Mencuci Tangan Sebelum dan Sesudah

Diberikan Pendidikan Kesehatan Pada Anak Usia 4-5 Tahun Tahun." Jurnal Keperawatan Soedirman.

20. Nursalam, and Ninuk DK. 2007. "Asuhan Keperawatan Pada Pasien Terinfeksi HIV/AIDS." 87-89. Jakarta: PT Salemba Medika.

21. W., E, N. \& S, M., 2012. Hubungan pengetahuan perawat tentang terapi infus dengan kejadian plebitis dan kenyamanan pasien di ruang rawat inap RSUD Kabupaten Indramayu. Depok: Fakultas Ilmu Keperawatan Universitas Indonesia. 